\title{
UM DIÁLOGO ENTRE A REALIDADE E A ARTE: A ESTÉTICA LUKACSIANA E GRACILIANO RAMOS
}

\section{Belmira Magalhães (UFAL)}

Para discutir a relação entre a materialidade histórica e a representação literária estabelecemos um diálogo intertextual entre os conceitos teóricos expressos na Estética de Lukács e os escritos graciliânicos, principalmente aqueles referidos como memorialistas (Memórias do cárcere e Infância).

A primeira afirmação necessária é a de que a relação entre história e representação literária não ocorre apenas naquelas obras comumente chamadas de "cunho social" ou expressões artísticas de escolas ditas realistas. Como afirma Jameson (1992:18):

Dessa perspectiva, a conveniente distinção entre textos culturais que são sociais e políticos e os que não o são torna-se algo pior que um erro: ou seja, um sintoma e um reforço da reificação e da privatização da vida contemporânea. Essa distinção reconfirma aquele hiato estrutural, experimental e conceitual entre o público e 0 privado, o social e o psicológico, ou o político e o poético, entre a História ou a sociedade e o "individual" - a tendenciosa lei da vida social capitalista -, que mutila nossa existência enquanto sujeitos individuais e paralisa nosso pensamento com relação ao tempo à mudança, da mesma forma que, certamente, nos aliena da própria fala.

A maneira de realizar artisticamente esse objetivo é atingir. como afirma Lukács na Estética (1966/67), a particularidade, conseguindo a interseção entre a universalidade e a singularidade, que ocorre quando o destino humano numa dada realidade histórica é o fio condutor do reflexo e, conseqüentemente, da crítica.

As condições de produção artística são parte das condições de produção na sociedade e estão relacionadas a elas; o fazer estético é parte do fazer social, isto é, a forma por excelência, encontrada pela humanidade para refletir sobre as possibilidades de elevação da sociabilidade a patamares superiores. Por esse motivo, em épocas de grandes questionamentos sobre os caminhos a serem seguidos, o 
reflexo estético ganha sempre maior expressão (as tragédias gregas e o Renascimento são exemplos desses períodos históricos).

Não importa o nível de consciência que o artista apresente em relação ao problema que consegue abordar, não há possibilidade de controle de tudo; mesmo assim, quando consegue refletir sobre a realidade de forma a apreender sua particularidade, torna possível a ampliação de sua obra através das diferentes leituras realizadas pela recepção e, mais especificamente, pela crítica literária.

A estética é uma forma de conhecimento humano colocada em um nível superior ${ }^{1}$ do conhecimento, diretamente ligada à práxis imediata da vida cotidiana, e que, no entanto, tem seu fundamento nas relações que acontecem nesse patamar da sociabilidade. A estética, a ciência e a prática cotidiana refletem a mesma realidade objetiva. Embora os resultados sejam distintos quanto à forma e ao conteúdo, há relações fecundas e recíprocas entre esses campos, que, inclusive, exercem estímulos uns sobre os outros. O marxismo enfatiza o caráter unitário do mundo refletido e, ao mesmo tempo, sublinha que, mesmo sendo socialmente condicionados, esses reflexos não podem ser realizados de forma mecânica, sem mediações.

Para a análise do reflexo estético nessa perspectiva, é essencial a apreensão da relação dialética entre as categorias de universalidade, particularidade e singularidade, pois compreendem o movimento ininterrupto no processo de reflexo da realidade de $\mathrm{um}$ extremo a outro (Lukács,1978:161). É a afirmação de Jameson (1992), segundo a qual o método dialético e a interpretação política da literatura são os únicos capazes de dar conta da essência mesma de uma obra.

Este livro vai argumentar em favor da prioridade da interpretação política dos textos literários. Ele concebe a perspectiva politica, não como método suplementar, não como auxiliar opcional de outros métodos interpretativos hoje em uso - o psicanalitico, o mitico-critico, o estilistico, o ético, o estrutural - mas como o horizonte absoluto de toda leitura,e de toda interpretação (p.15).

Nível superior significa um nível de abstração e de elaboração que extrapola a práxis cotidiana e se dirige à relação da individualidade com a generidade. 
O reflexo estético se impõe à tarefa de compreender, descobrir e reproduzir com seus meios especificos a totalidade da realidade em sua explicitada riqueza de contenidos e formas (Lukács:1978,161), provocando modificações qualitativas na imagem reflexa do mundo e, simultaneamente, na subjetividade.

A particularidade fixada sob o mundo formal da obra de arte é uma expressão que não poderá ser modificada, sob pena de destruição da própria obra. ${ }^{2}$ Tanto a universalidade como a singularidade são superadas na particularidade, que, nesse instante, fixa um grau de desenvolvimento da humanidade para a consciência humana. Essa superação não significa desaparecimento, mas a conservação dessas esferas, principalmente o papel desempenhado pela universalidade, já que toda obra de valor deve discutir a relação entre individuo e gênero humano.

Diferentemente da ciência, cujas descobertas são sempre cumulativas ${ }^{3}$, cada etapa de desenvolvimento artístico representa um recomeço e não uma continuidade vinculada à precedente. Cada obra de arte encerra-se em si mesma. A confecção de outra obra não parte da anterior, pois, enquanto obra, é um novo momento. ${ }^{+}$

Embora as relações sociais e de classe, refletidas em São Bernardo e Vidas secas, sejam semelhantes e a tendência literária que influenciava o autor não houvesse sofrido nenhuma mudança substancial, os dois romances são diferentes quando considerados em sua totalidade. Nesse sentido, quando se realiza uma análise do interior da obra literária, as comparações, embora possam ser elaboradas, apresentam-se apenas como um suporte da análise, a não ser que a análise comparativa realize a crítica imanente de cada obra, para depois, então, compará-las. Segundo Lukács, para a elaboração de uma obra:

Existe um complexo muito complicado de influências reciprocas entre situação social, concepção do mundo, penetração artistica e intenção da personalidade criadora em uma determinada e determinante situação histórica, o que decide o modo de escolha e de aplicação de uma técnica concreta (1978:191).

2 Não se está discutindo, aqui, o papel do leitor, espectador, público etc.. mas o momento e o movimento explicitado na obra.

3 Ver KUHN [s.d.] em seu estudo sobre os paradigmas científicos.

4 Os recursos técnicos são aperfeiçoados, a experiència do artista ao usá-los aprimora-se, a cada nova realização, mas o ato de criar é único. 
Madalena e sinha Vitória apresentam, aparentemente, muitas semelhanças enquanto personagens femininas fortes, desencadeadoras do movimento dos romances, mas o lugar de cada uma nas obras só tem sentido quando analisado dentro da totalidade das marcas da autoria de cada obra tomada de per si, pois a composição da personagem está sujeita a uma variação de convenções que dependem do todo da obra. No entanto, como afirma Williams (1979), a montagem da personagem depende da aceitação de sua convenção. mas é sempre mais do que uma decisão 'literária' ou 'estética' (p.174). Esta especificidade enfatiza a necessidade de análises comparativas a partir de critérios bem definidos, pois

por trás de todo julgamento desta espécie, deve sempre estar a fundamental experiência estética das referidas obras singulares, tomadas em si; e que nesta experiência, sobretudo, quem julga está inevitavelmente em face, sempre e apenas, de uma determinada obra; a comparação entre obras pressupōe sempre essa base preliminar, sem a qual escaparia a quem julga precisamente a essência estética das obras confrontadas e o seu julgamento, a sua comparação, seria privada de valor estético (Lukács,1978:243-4).

É na superação da singularidade e da universalidade na particularidade artistica que sobressaem as determinações que compõem o conjunto necessário ao reflexo estético: o período, o gênero e a individualidade do artista. Todas essas variações, em última instância, apresentam a certeza de que a sua fonte mais profunda advém dos fenômenos concretos, obra de homens e mulheres concretos. Nas palavras de Graciliano Ramos:

Não resguardei os apontamentos obtidos em largos dias e meses de observação: num momento de aperto fui obrigado a jogá-los na água. Certamente me irão fazer falta, mas terá sido uma perda irreparável? Quase me inclino a supor que foi bom privar-me desse material. Se ele existisse, ver-me-ia propenso a consultá-lo a cada instante, mortificar-me-ia por dizer com rigor hora exata de uma partida [...] Mas que significa isso? Essas coisas verdadeiras podem não ser verossimeis. [...] Nessa reconstituição de fatos velhos, neste esmiuçamento, exponho o que notei, o que julgo ter notado. Outros devem possuir lembranças diversas. Não as contesto, mas espero que não recusem as minhas: conjugam-se, completam-se e me dão hoje impressão de realidade (Memórias, 1994:36). 
As dúvidas de Graciliano sobre a importância da verdade e da verossimilhança, mesmo neste texto de cunho memorialista, demonstram a tentativa de controle do literato sobre seus escritos, mas. acima de tudo, confirmam que a obra estética, embora parta de uma singularidade, precisa superá-la, sob pena de se tornar um retrato, até certa forma verdadeiro, de um fato histórico, mas não uma obra artistica.

Candido (1993) introduz a noção de coerência como fundamental para estabelecer a especificidade do texto ficcional, superando a relação, por vezes enganosa, entre verossimilhança e verdade:

Conclui-se que a capacidade que os textos possuem de convencer depende mais da sua organização própria que da referência ao mundo exterior, pois este só ganha vida na obra literária se for devidamente ordenado pela fatura. Os textos [...] suscitam no leitor uma impressão de verdade porque antes de serem ou não verossimeis são articulados de maneira coerente (p.11).

O reflexo artístico não está condicionado ao conhecimento fïlosófico nem ao científico, pois isso implicaria exigir do artista a função de um historiador para entender o tempo e a de um filósofo para questionar cada tempo. Mas, pode-se estabelecer uma relação positiva entre o conhecimento do artista sobre a realidade objetiva e a capacidade de refletir esteticamente essa objetividade. Para Lukács (1978), transformar uma objetivação fruto de uma individualidade em generalização estética, em particularidade, só ocorre após o esforço de reproduzir fielmente a lógica da essência de uma realidade.

A superação do singular e do universal na particularidade que resulta da descoberta do ponto central médio e significa o caso típico, pode ser resumida para sua elaboração na seguinte série: leis universais de estética geral (o reflexo estético e sua especificidade); leis particulares do gênero (cada gênero estético necessariamente cria seus próprios códigos, que se expressam na concretude de suas obras); diferenciação histórica do desenvolvimento dos gêneros (cada gênero possui relação com os demais e, ao mesmo tempo, guarda autonomia em relação a eles, seu desenvolvimento histórico possui um dinamismo, um movimento próprio que pode acelerar, em determinado momento, a criação em certas áreas, ou inibir certas características de um gênero em determinado momento histórico); 
e, finalmente, a configuração individual da obra de arte singular, a definição e fixação do ponto central.

Por isso, a constatação, dessa perspectiva teóricometodológica, de que só pelo exame da obra de arte, em sua concretude, pode-se chegar ao ponto central, à particularidade fixada pelo reflexo estético. A configuração de uma obra individual dependerá sempre do ponto central escolhido pelo artista, que se relacionará à universalidade e à singularidade. Essa escolha determinará um movimento em torno do particular que traduzirá a unidade da obra. Nas palavras de Lukács:

Essa afirmação expressa, ademais, um fato estético universalmente notório e reconhecido, isto é, o fato de que o estilo, o tom, a atmosfera de uma obra artística podem permanecer perfeitamente unitários mesmo se - no quadro dessa unidade - dominarem grandes altos e baixos, mesmo se determinados momentos da obra se aproximarem mais do que outros da universalidade ou da singularidade, mas sempre na condição de que esses movimentos ocorram no interior da mesma esfera da particularidade e que todos mantenham entre si estreita relação ideal e formal (Lukács,1978:173).

A essência da arte será obtida, então, pela organização artística do mundo, que será realizada a partir do movimento que carrega todas as tensões e contrastes. Como diz Graciliano: Meu pai fora um violento padrasto, minha mãe parecia odiar-me, e a lembrança deles me instigava a escrever um livro a respeito da bárbara educação nordestina (Memórias, 1994:178).

Os elementos indispensáveis à concepção e ao momento histórico fixado estão em relações recíprocas com as condições histórico-sociais do gênero e com as artístico-pessoais. A obra de arte não pode confundir-se com a realidade objetiva da qual é um reflexo; ao mesmo tempo, ela é uma realidade que não pode ser modificada a partir das idéias e desejos do receptor, sem levar em consideração a sua própria essencialidade, pois qualquer obra de arte é uma realidade material sensivel, cuja superação da universalidade e da singularidade na particularidade representa uma conservação que precisa ser apreendida.

Paralelamente, toda obra de arte representa uma superação que permite sua recepção em épocas históricas diferentes. Subjetivamente, 
pode-se apenas aprová-la ou não, mas não se pretender análises de caráter objetivo.

Como foi salientado, a realidade apresenta-se ao homem na sua forma particular; as coisas têm sempre ontologicamente uma característica que as torna, ao mesmo tempo, universais e singulares, por isso, particulares. Um determinado objeto mostra-se na sua mais infinita singularidade, e, no entanto, só é possível existir porque contém nele todo o universal que possibilita essa singularidade. O particular é o encontro do universal com o singular, essas são categorias prioritárias do real.

Para que haja apreensão do real pela subjetividade, há necessidade de, a partir da particularidade, captar a singularidade e a universalidade. O texto de Graciliano Ramos que se segue ilustra, com exemplaridade, a relação entre essas categorias e a forma de apreensão que cabe à subjetividade:

Talvez nem me recorde bem do vaso: é possivel que a imagem, brilhante e esguia, permaneça por eu a ter comunicado a pessoas que a confirmaram. Assim, não conservo a lembrança de uma alfaia esquisita, mas a reprodução dela, corroborada por individuos que the fixaram o conteúdo e a forma. De qualquer forma a aparição deve ter sido real. Inculcaram-me nesse tempo a noção de pitombas - e as pitombas me serviram para designar todos os objetos esféricos. Depois me explicaram que a generalização era um erro, e isto me perturbou (Infância, 1995:7).

Na verdade, o escritor está nos falando do processo de apreensão do mundo e dos diversos níveis em que isso pode efetuarse. A apreensão cognitiva desse real só é possível através de categorias intelectivas que tornem possivel a captação dessa relação de singularidades e universalidade. A personagem criança generaliza excessivamente o singular [pitombas] a partir de um universal [forma esférical só possivel nessa fase, que o adulto corrigirá.

Diferente é a posição do escritor adulto que, a partir de uma particularidade - 0 vaso - que existia na infância. constrói uma reflexão sobre um momento, realizando o movimento de apreensão do real pelo sujeito, reclaborando-o e devolvendo-o à realidade sob a forma do texto graciliânico. 
A fundamentação teórica da análise de um objeto precisa ser simples. ao ponto de permitir uma compreensão clara do embasamento que será usado para explicitar o objeto e, ao mesmo tempo, precisa conter toda a complexidade necessária ao completo abarcamento da realidade que se pretende expor.

O reflexo estético também deve acompanhar esse movimento, que vai do simples ao complexo e deste ao encontro de outros complexos que, embora não sejam estéticos diretamente, são fundamentais para a captação artística.

Assim é o romance Vidas secas, que consegue refletir, ao mesmo tempo, a particularidade do latifúndio no Brasil dos anos trinta e as questões fundamentais do gênero humano e do papel da arte na constituição do ser social, que estavam postas para o seu tempo histórico.

Em Memórias do cárcere, Graciliano expressa a consciência que possuía das relações que reproduzira em seus livros sobre o campo.

Muitos anos seriam precisos para despertar essas massas enganadas, sonolentas - e a propaganda feita em alguns meses naturalmente fora escassa.[...] Lembrava-me de um desses conselhos, negro, a piche: "Índios uni-vos." Nunca vi maior disparate, pois naquele arrebalde de capital pequena não vivia nenhum indio. [...] E para que nos serviria a união dos indios, santo Deus? Absurdos semelhantes pressupunham desorientação (Memórias, 1994:83).

O transplante de palavras de ordem que diziam respeito a uma realidade posta e a uma classe social, sem nenhuma mediação, produz absurdos do tipo que Graciliano assinala na citação acima, demonstrando, também, a necessidade de conhecimento da objetividade tanto para o sujeito politico que pretende uma intervenção direta na realidade, como para o artista que realiza o reflexo estético sobre a mesma realidade.

Nesse tipo de abordagem, a primeira afirmação, não por ser mais importante do que as que se seguirão, mas pela precedência que impõe. é a de que toda práxis humana pressupõe a existência de duas categorias ontológicas - subjetividade e objetividade ${ }^{5}$, que possuem autonomia, mas que não podem ser pensadas separadamente. O mundo

Para melhor desenvolver esse tema veja Marx, 1978. 
real e o sujeito cognoscente não podem ser confundidos, nem mesmo quando o fruto dessa relação é uma obra de arte.

A materialidade expressa em uma obra de arte traz a marca da subjetividade que a produziu, mas não no sentido de ser a expressão da individualidade do autor, pois o que está ali expresso é a relação entre uma individualidade, posta em um tempo e espaço definidos historicamente, e uma realidade que está sendo representada por essa individualidade, com consciência do que está fazendo, mas sem o domínio de todas as alternativas postas por essa mesma realidade. Ao se referir aos seus escritos, Graciliano, embora tenha clareza do que escreve, percebe a autonomia que a obra de arte adquire em relação ao seu criador: 6

Era uma história repisada, com voltas infinitas ao redor do mesmo ponto, literatura de peru. Como arte e como politica valia bem pouco, mas talvez enxergassem nela dinamite (Memórias, 1994:97).

Embora Graciliano Ramos afirme que seus escritos não valiam grande coisa, percebe, perplexo, que não tem controle sobre eles após a publicação. O uso ideológico/prático de qualquer criação humana não está sob o controle do criador após a inserção no meio social. Por mais previsível que seja a forma de utilização da criação humana, nunca há certeza de quais serão os resultados da objetivação.

A capacidade de realizar ações planejadas pela consciência constitui a marca que diferencia os seres sociais das outras espécies animais. A teleologia que cada sujeito imprime à realidade só é possivel porque essa individualidade foi capaz de antever $O$ movimento da realidade, que permitirá a realização de uma ação previamente pensada/planejada. No entanto, após esse ato, não há condições de prever a forma como ele será absorvido socialmente, nem o limite dessa absorção.

${ }^{6} \dot{E}$ importante ressaltar aqui que toda teleologia é essencialmente individual, mas o resultado desse processo é social e seu desenvolvimento independe da subjetividade que the deu origem. Ver Lukács, 1992.

Nào estamos aqui nos referindo exclusivamente à arte, mas a qualquer teleologia imprimida no real. 
Esse processo tem início a partir do salto ontológico ${ }^{8}$ que cria a possibilidade de um ser vivo desligar-se do condicionamento único das leis da esfera da vida, que o prendia à condição de repetir sempre os mesmos atos, posto que subsumidos à lógica biológica; após esse deslocamento, não há retorno ao lugar anterior, iniciando-se o processo de humanização do gênero humano. O ser social que surge dessa mudança ontológica possui a capacidade de pensar com objetivo prático.

Dizendo de outra forma, o ser social surge com a associação do pensamento à ação, através da capacidade da prévia-ideação, que realiza o planejamento da ação antes de sua execução. Para que isso fosse possível, foi necessária a constituição de uma linguagem qualitativamente nova, condição intrínseca para a leitura do mundo realizada pelo pensamento. Marx sintetiza a relação entre subjetividade e objetividade:

A produção de idéias, de representaçōes, da consciência está, desde o início, diretamente entrelaçada com a atividade material dos homens, como a linguagem da vida real. O representar, o pensar, o intercâmbio espiritual, dos homens, aparecem aqui como emanação direta do seu comportamento material (Marx,1965:21).

A novidade do aparecimento do novo ser é sua condição intrinseca e ontológica de ser sujeito, imprimindo de forma consciente" sua marca na objetividade como meio de suprir antigas e novas necessidades. Para que a criação do novo aconteça, é preciso que as mudanças cheguem até a consciência para conservá-las e promover a reprodução através da generalização social. É nesse processo que a linguagem cumpre a sua função: fixar na consciência as aquisições, conservando-as e superando-as a partir do desenvolvimento de novas perguntas e novas respostas.

Um salto ontológico é promovido por diversos fatores pré-existentes que, reunidos, criam um novo ser, com uma lógica inteiramente diferente que o faz ontologicamente diverso dos seres anteriores. Ver Lukács, 1979.

Consciente, aqui, não significa o domínio racional de todo o processo. mas apenas a intencionalidade do sujeito de pensar uma ação. Para desenvolvimento do tema, ver lukacs (1966-67), principalmente o caputulo sobre o trabalho. e Bakhtun (1990). 
Desde o inicio pesa sobre o espirito a maldição de estar contaminado pela matéria que se apresenta sob a forma de camadas de ar em movimento de sons, em suma de linguagem (Marx,1965:43).

Descobrindo o que até então era ignorado, aparecem novos contcúdos com múltiplas formas que exigem uma negociação comminicativa ${ }^{10}$ entre os sujeitos. Esse novo ser, aparentemente dotado de poder absoluto para transformar o real, se depara com um limite intransponivel, pois colocado fora de si - pertencente ao locus da objetividade - detém o limite da ação da subjetividade.

A subjetividade, que percebe carências, precisa conhecer a legalidade da objetividade para nela interferir, mas apenas dentro das possibilidades permitidas por essa mesma objetividade, e. efetivamente, com o nivel de conhecimento que essa subjetividade, que é individual e histórica, possui.

Nos atos singulares de criação ou de recepção, de aprovação ou de recusa, os indivíduos podem ter desde uma participação mínima até uma interferência decisiva no processo geral, sendo nesse sentido que a linguagem é entendida como medium que possibilita, ao mesmo tempo, a fixação e a transformação do código.

Quanto mais a subjetividade artística tender para o descobrimento e revelação do novo, tomando uma posição a favor das novas possibilidades que surgem, tanto mais terá condições de promover o movimento dialético necessário a uma interferência efetiva no real.

A razāo decisiva graças à qual uma obra conserva uma eficácia permanente, enquanto outra envelhece, reside em que uma capta as orientações e as proporções essenciais do desenvolvimento histórico, ao passo que a outra não conseguiu (Lukács, 1978:240).

Assim como Marx afirma, referindo-se a Balzac, que este conseguiu antecipar, através da composição dos personagens da Comédia humana, momentos históricos posteriores, pode-se argumentar que Graciliano, em 1938, ao deixar as personagens no

11) Para Lukács (1990:68-88), esse aspecto está diretamente ligado à necessidade de intercâmbio entre os sujeitos na produção e reprodução social de suas existências, fazendo parte do caráter social do gênero humano. 
meio da estrada em direção ao Sul, antecipou o que ocorreria durante o processo de industrialização da sociedade, que se utilizaria dos braços nordestinos para construir o parque industrial. Ao mesmo tempo, há a confirmação da impossibilidade de transformação da realidade do sertanejo sem uma transformação efetiva de toda a sociedade. Durante a comemoração dos sessenta anos de publicação de Vidas secas, constata-se que novos fabianos continuam caminhando pelo sertão, fugindo da seca.

Sem a interferência da subjetividade é impossivel qualquer escolha entre as alternativas existentes na objetividade, que funcionaria apenas com sua lógica interna ou ao sabor do acaso ${ }^{11}$. Na verdade, é o surgimento da subjetividade que instaura o ser social, e a história do gênero humano é a história da intervenção da subjetividade na objetividade. É nessa relação que se consubstancia a força do sujeito.

O limite da subjetividade é dado pela objetividade, que não permite qualquer tipo de intervenção, mas apenas aquelas que condizem com sua legalidade. Nesse sentido é que uma subjetividade precisa do conhecimento mais apurado possível, da lógica do objeto a sofrer sua interferência, para que as práticas possuam possibilidade de eficácia. Graciliano se refere a essas características da objetividade, que o afetam enquanto escritor:

Liberdade completa ninguém desfruta: começamos oprimidos pela sintaxe e acabamos às voltas com a Delegacia de Ordem Politica e Social, mas, nos estreitos limites a que nos coagem a gramática e a lei, ainda nos podemos mexer (Memórias, 1994:34).

Marx dá um passo decisivo para estabelecer o papel da subjetividade na construção do ir-sendo do ser social, ou seja, é a subjetividade que instaura a possibilidade de um mundo humano/social, mas não uma subjetividade autônoma que se impõe idealmente à realidade. Na verdade, tem-se uma subjetividade objetivada, isto é, um sujeito que possui história, por isso, limites na construção ideal e efetiva de suas realizações.

As críticas a essa perspectiva teórico/metodológica estão sempre enfatizando que o sujeito da teoria marxista, por ser uma teoria

1 A legalidade do mundo incrgânico e do orgânico, que não pressupõe a criação do novo. 
materialista, é assujeitado, realizador automático das imposições da objetividade. No entanto, como foi salientado acima, inclusive com o testemunho de Graciliano Ramos, o fato de não absolutizar a capacidade do sujeito de criar o que quiser a partir única e exclusivamente de sua vontade, não retira da subjetividade a capacidade criadora, nem a importância crucial de sua ação para a reprodução do ser social.

Essa conceituação não se limita à criação artística, mas se refere, como já foi dito, à própria possibilidade de efetivação do ser social, pois que está na base ontológica de sua processualidade enquanto ser. A voz do mundo é a voz do sujeito, que é o único ser capaz de falar do mundo e de si; sendo o mundo o limite, é levado a falar apenas o que deste consegue apreender, de vez que só pode falar de si enquanto ser no mundo, isto é, histórico. Em uma passagem de Infância (1995), o entrelaçamento entre objetividade e subjetividade artística se evidencia a partir do movimento que produz o reflexo artístico: houve um verão, criaram-se imagens, atribuiu-se-lhe realidade na obra efetivada.

Desse antigo verão que me alterou a vida restam ligeiros traços apenas. $E$ nem deles posso afirmar que efetivamente me recorde. O hábito me leva a criar um ambiente, imaginar fatos a que atribuo realidade. Sem dúvida as árvores se despojaram e enegreceram, o açude estancou, as porteiras dos currais se abriram, inúteis. É sempre assim (p.23).

Assim é que não há uma individualidade. nem produção individual. que não seja essencialmente social e histórica:

Ainda quando realizo trabalho cientifico, artistico, etc. uma atividade que raramente posso conduzir em associação direta com outros homens, efetuo um ato social, por ser humano. Não é só o material de minha atividade como a própria lingua, que o pensador utiliza - que me é dado como um produto social. Minha própria existência é uma atividade social. Por essa razão, o que eu próprio produzo o faço para a sociedade, e com a consciência de agir como um ser social (Marx,1964:125).

Como parte do ser social, a subjetividade pode ter diversos graus de conscientização sobre o seu estar no mundo, e, em conseqüência, ter maior ou menor possibilidade de compreendê-lo, mas a explicação para sua atividade no mundo não será dada por 
nenhuma condição que não possua explicação na própria sociabilidade, mesmo que a subjetividade contemporânea ao sujeito que faz determinada leitura do mundo não possa alcançá-la, tendendo a buscar soluções transcendentais, ignorando as inovações.

Entende-se, pois, a afirmação da concepção marxiana de que a vida individual e a genérica não constituem entidades autônomas que se relacionam, mas, ao contrário, são parte de um todo impossível de ser dissociado. Graciliano, descrevendo a seca e a conseqüente mudança das relações entre as pessoas, nos mostra a imbricação entre a vida de cada um e a de todos.

O meu verão é incompleto. O que me deixou foi a lembrança de importantes modificaçōes nas pessoas. De ordinário pachorrentas, azucrinaram-se como tanajuras, zonzas. Findaram as longas conversas no alpendre, as visitas, os risos sonoros, os negócios lentos; surgiram rostos sombrios e rumores abafados. Enorme calor, nuvens de poeira. E no calor e na poeira homens indo e vindo sem descanso, molhados de suor, aboiando monotonamente (Infância, 1995:23-4).

As relações sociais modificam o estar no mundo dos homens, o verão incompleto do narrador adulto de Infância refere-se à ausência de férias para o personagem menino, já que nos países tropicais é durante essa estação que são interrompidas as aulas. Como poderia ser associado a lazer um momento em que as pessoas se transformavam de pachorrentas em tanajuras, zonzas, os risos sonoros e rostos alegres em rumores abafados e rostos sombrios? Por mais individualidade que o escritor possua, tornando-o capaz de refletir sobre tal situação, marcando sua pessoalidade, sua inserção no meio é dada pela noção clara de que em uma situação de carência não há possibilidade de completude, por isso o narrador afirma, ao trazer o passado para o presente: o meu verão é incompleto.

$\mathrm{Na}$ verdade, não há individualidade sem gênero humano, como não há generidade sem indivíduos capazes de se reconhecerem como tais e, por isso, conscientes de seu estar-no-mundo' ${ }^{12}$. Nas palavras de Marx,

12 Este tema será desenvolvido mais adiante. No entanto, é importante se destacar desde já que esse contínuo é que marca a diferença entre uma individualidade que não conseguirá se deslocar do cotidiano, de outra que será capaz, por exemplo, de produzir Vidas secas. 
A vida individual e a vida-espécie não são coisas diferentes, conquanto o modo de existência da vida individual seja um modo mais específico ou mais geral da vida-espécie, ou da vida-espécie seja modo mais específico ou mais geral da vida individual (Mar火,1964:125).

Depreende-se dessas afirmações que não há uma oposição ontológica ${ }^{13}$ entre indivíduo e sociedade, mas sim entre sujeito, ser social genérico e a natureza. Na verdade, a oposição entre natureza e cultura se dá pela intervenção da subjetividade, que tem consciência de si e da natureza.

Há um nexo entre subjetividade, sociedade e produção das idéias, e, nela, a produção artística, no caso específico desse trabalho, a produção literária. A arte, a mais elevada das expressões humanas, reflete as relações entre o indivíduo e o gênero, desempenhando papel fundamental no desenvolvimento da subjetividade. A gênese da arte parte de necessidades interiores do indivíduo ${ }^{1 \cdot 4}$, em sua existência material concreta, e necessariamente tem de se deslocar da imediaticidade do cotidiano. Seguindo essa linha de raciocínio, podese afirmar a existência de um conflito interno e insolúvel para a expressão artística: nenhuma sociedade pode satisfazer todas as paixões humanas, mas só no espaço social as paixões humanas podem ser realizadas, mesmo que apenas de forma artística.

A arte constitui uma expressão privilegiada da subjetividade; - resultado do reflexo artístico e sua recepção são possibilidades concretas de afirmação da personalidade, pois significam o ato de escolha que um sujeito - o artista, ou o receptor - realiza sobre a forma de tratar os conflitos, que estão diretamente ligados à autoconstrução humana.

O pensamento mágico também é uma forma de resolução dos problemas sociais, que não encontram resposta na realidade concreta: no entanto, diferentemente da arte, não contribui para a formação da subjetividade, ao contrário, anula-a, pois desloca para outros seres que não homens e mulheres concretos, a resolução das dificuldades

1) A oposição entre individuo e sociedade pode se dar quando a sociabilidade é inibidora da individuação. mas sempre tendo-se como ponto de partida que a escolha de uma sociabilutale opressora é produzida pela relação entre os seres sociais.

14 Que, de resto, não são resolvidas só pela arte 
A subjetividade é apagada e reduzida a simples executora obediente de regras impostas por esse tipo de expressão humana que desloca o eixo das resoluções da realidade histórico-social.

Ratificando, tem-se que a arte, ao contrário do pensamento mágico, parte de indivíduos concretos e retorna a eles através da recepção, sendo, em todas as suas fases, um fenomeno essencialmente social. O resultado do fazer artístico representa uma visão de mundo. sem haver uma relação mecânica entre o que o artista pensa sobre o mundo e o que ele expressa em sua obra. O ato artístico é sempre consciente, o sujeito que o realiza tem consciência do que quer realizar, embora não tenha controle total sobre a capacidade de dar forma ao seu objetivo, nem da totalidade de interpretações que poderão advir de sua intencionalidade ${ }^{15}$. expressa na obra. Essa intencionalidade é reafirmada por Bakhtin (1992) através do conceito de intuito discursivo, que pressupõe o querer dizer do autor de um texto:

Em qualquer enunciado, desde a réplica cotidiana monoleximática até as grandes obras complexas cientificas ou literárias, captamos, compreendemos, sentimos o intuito discursivo ou querer dizer do locutor que determina o todo do enunciado: sua amplitude, suas fronteiras. [...] O intuito, o elemento subjetivo do enunciado, entra em combinação com o objeto do sentido - objetivo para formar uma unidade indissolúvel, que ele limita, vincula à situação concreta (única) da comunicação verbal, marcada pelas circunstâncias individuais, pelos parceiros individualizados e suas intervenções anteriores: seus enunciados (p.300).

A relação conteúdo e forma está sempre indissociada: a intenção do autor é objetivada no mundo da obra de arte sob determinada forma, que não poderia ser outra e que constitui o momento do reflexo, isto é, a marca da individualidade no real. Nessa atividade humana, o momento pessoal tem importancia constitutiva de toda objetividade e, dialeticamente, é imprescindivel à ultrapassagem do cotidiano imediato. Na verdade, há um duplo aspecto a ser considerado: todo processo de objetivação do fazer estétıco é orientado pelo momento subjetivo, que pressupõe leitura do mundo.

Intencionalidade que significa o pòr do sujeito no mundo, o agir com objetivo, a partir de uma reflexão prévia sobre o ato. 
intencionalidade, conhecimento técnico e, se possivel, genialidade; e, ao mesmo tempo, todo resultado obtido possui pretensão de validez objetiva. Nas palavras de Lukács (1978):

Como vimos, a particularidade como categoria especifica do campo estético é, negativamente, a renúncia a reproduzir a totalidade extensiva da realidade; e, positivamente, a representação de uma "parte" da realidade, representação que - reproduzindo a sua totalidade intensiva e a direção do seu movimento - clarifica a realidade através de um determinado e essencial ponto de vista (p.267).

É isso que Graciliano faz ao representar as condições do latifúndio e opinar de forma estética sobre a impossibilidade, naquele estágio em que se encontravam as relaçôes sociais no campo brasileiro, de mudança a partir do próprio campo. A solução que seus personagens imprimem a suas vidas não indica transformações das relações latifundiárias, mas mudanças signilicativas na forma de viver para aqueles que abandonam o campo.'

O reflexo estético necessita de um nivel de consciência mais elaborado do que a práxis responsável pelo processo de trabalho, cuja relação sujeito/objeto se dá a partir de uma necessidade essencialmente prática. Quando nos referimos ao nível de consciência, não estamos afirmando a existência de uma consciência plena de todos os processos sociais e históricos envolvidos na reflexão artística, mas na certeza, necessária ao artista, de que está realizando uma práxis com um valor e códigos específicos a cada expressão artística. Em outras palavras, a especificidade do reflexo artístico implica consciência do ato como artístico: o objeto pode ser uma obra de arte, mas só se percebido socialmente, por exemplo, como finalidade prática de objeto de uso cotidiano. É por esse motivo que Lukács afima, na Estética, que o reflexo artístico se constitui, após a concretização do campo científico. devido à necessidade primeira de resolução de problemas ligados diretamente à sobrevivência do ser social:

Isto basta para explicar o relativamente tardio aparecimento do reflexo estético em comparaçāo com o trabalho: o estético pressupõe, materialmente, uma determinada altura da técnica e, além disso, um ócio para a

16 Não está em jogo a justeza desse ponto de vista, mas o esclarecimento do ponto de vista autoral. 
criação de "superfluidade", determinada pelo aumento das forças produtivas do trabalho (Lukács, v.1, 1966-67:251).

Para esse autor, só na arte é possível a afirmação de que "não há objeto sem sujeito" (1966-67:227), acrescentando logo em seguida que, embora possivel esse fato, o objeto criado pelo reflexo estético tem uma existência material independente da do sujeito, mas não uma independência estética, porque só o sujeito é capaz de transformar um objeto em um objeto artístico.

A relação dialética entre a alienação na produção do objeto e a retrocaptação na recepção do mesmo constitui um dos traços fundamentais do reflexo estético, o fundamento da marca da subjetividade diferenciadora dessa atividade humana. Nas palavras de Lukács:

A alienação significa caminho do sujeito ao mundo objetivo, às vezes até o perder-se do sujeito nele; a retrocaptação ou reabsorção de uma tal alienação representa, pelo contrário, a penetração completa de toda objetividade assim nascida pela qualidade particular do sujeito (v.2, 1966-67:237).

É necessário o esforço do reflexo estético para captar todo objeto em conexão com a subjetividade humana $\mathrm{em}$ geral (universal) e, ao mesmo tempo, perceber como esse todo se apresenta, se manifesta, na imediaticidade histórica (singular), isto é. um reflexo da realidade que seja capaz de impor as impressões e vivências da cotidianidade e, simultaneamente, estar impregnado de subjetividade como elemento insuperável de seu ser-assim. Assim deve ser tomada a relação Arte e História, ou seja, a partir da concepção que entende um entrecruzamento de coisas distintas e indissociáveis que possuem objetos e formas de expressar diferentes.

Nessa abordagem. afirma-se que nenhuma obra de arte pode ser estudada sem o auxilio da listória, pois a verdaderra arte é um fa/er história, na medida em que i um refletir do ser social sobre sut propria existência. Não é história porque o autor resolveu contar o seu lempo, mas porque ele reflete sobre o seu tempo e as possibilidades de ultrapassá-lo. Como Gracıliano Ramos faz cm ridas secas, refletindo sobre as condições do camp̣o brasilerro, na década de trinta, e conduzindo as personagens por um caminho que parecia o único possivel. 
Em consonância com essa forma de perceber o reflexo estético, pode-se também afirmar que toda a objetivação artística possui um ponto de vista autoral. Na verdade, estamos nos referindo ao posicionamento do autor sobre a realidade refletida na obra, a marca de sua intencionalidade ao escolher aquele conjunto de códigos e não outro para refletir na sua obra:

A eleição de um grupo contextual de objetos, sua conversão e mundo mediante a refiguração e a conformação mimética, è impossivel sem uma tomada de posição com respeito àquele conteúdo e suas conexões. tomada de posição que constitui o ser-assim da parte do mundo eleita e sua elevação ao "mundo" estético (Lukács, v.2, 1966-7:241).

Reforçando essa argumentação, Bakhtin (1990), no estudo que faz da relação entre subjetividade e objetividade, afirma:

Um signo não existe apenas como parte de uma realidade; ele também reflete e refrata uma outra. Ele pode distorcer essa realidade, ser-lhe fiel, ou apreendê-la de um ponto de vista especifico, etc. Todo signo está sujeito aos critérios de avaliação ideológica (p.32).

E na linguagem literária de Graciliano Ramos:

Dúvidas terriveis nos assaltam. De que modo reagiram os caracteres em determinadas circunstâncias? [...] Nessas vacilaçōes dolorosas, às vezes necessitamos confirmação, apelamos para reminiscências alheias, convencemo-nos de que a minúcia discrepante não é ilusão. Dificil è sabermos a causa dela, desenterrarmos pacientemente as condiçōes que as determinaram. Como isso varia em excesso, era natural que variássemos também, apresentássemos falhas (Memórias ,1994:37).

É com essa concepção que estamos tratando das marcas de autoria, o que não requer, sob essa perspectiva, nenhuma incursão sobre as características psicológicas do autor como forma explicativa de sua composição autoral. Bakhtin, ao discutir a relação entre objetividade e consciência, sintetiza a questão da seguinte forma:

Tudo que dissemos acima conduz ao seguinte principio metodológico: o estudo das ideologias não depende em nada da psicologia e nāo tem nenhuma necessidade dela. Como veremos, é antes o contrário que é 
verdadeiro: a psicologia objetiva deve se apoiar no estudo das ideologias (Bakhtin, 1990:36).

A ação da subjetividade artística, embora expresse a relação de um indivíduo com o mundo, não significa o posicionamento dessa subjetividade sobre as coisas da práxis imediata, pois, sendo a arte antropomórfica por natureza e função, encontra-se no âmbito das ideologias secundárias, que têm por objetivo o comportamento dos outros homens, isto é, provocar uma mudança para uma nova posição ideológica (Vaisman, 1989:415).

A afirmação de Vaisman remete à questão da intencionalidade da ação de todo reflexo estético. Embora expressão ideológica, a arte nào tem pretensão nem compromisso de promover mudanças nas relações sociais que são contemporâneas do artista; o caráter ideológico da obra de arte é intrínseco a qualquer reflexo artístico, por mais aparentemente abstrato ou fora da realidade que uma obra de arte possa parecer ou pretender que seja sua autoria.

A noção de ponto de vista desenvolvida pela teoria da literatura está sempre intimamente ligada às personagens em geral, ao protagonista, em particular, ou ao narrador. Partindo dessa vinculação. é apresentada uma série de classificações sobre a forma como o ponto de vista é expresso: narrador onisciente, sem narrador, opinativo, de forma não opinativa etc., concluindo-se que pode haver uma variedade de pontos de vista numa mesma obra. ${ }^{17}$

Raymond Williams (1979) faz um paralelo entre 'o ponto de vista' estritamente estético, que diz respeito à estrutura narrativa, e o ponto de vista autoral, que, necessariamente, relaciona-se com o primeiro, mas parte do embricamento do escritor com a realidade que está refletindo.

As descrições de grandes casas, de paisagens rurais, de cidades, ou de fábricas säo exemplos evidentes dessas convenções variáveis, onde 'o ponto de vista' pode ser considerado como uma escolha 'estética', mas onde qualquer ponto de vista, inclusive aquele que inclui pessoas ou as transforma em paisagem, é social (p.176).

Diversas classificações são apresentadas em CARVALHO. Alfredo I eme Coelho de. Foco narrative e fluxo de consciencia: questöes de teoria da literatura. São Paulo, Pioneira:1981. 
O ponto de vista variável no decorrer da obra pode expressarse através de narradores, personagens diversas; no entanto, o ponto de vista autoral, definido como a posição particular da qual se avalia ou se considera alguma coisa. leva o escritor a fazer recortes da realidade. realizando a escolha da forma mais adequada ao seu fazer artístico. Nesse sentido, o ponto de vista autoral terá de ser, necessariamente. unitário e coerente com a posição que o autor imprime na obra. Nas palavras de Williams (1979):

A chave de qualquer análise, e da análise de volta à teoria, é então o reconhecimento de situações precisas nas quais o que foi isolado, e deslocado, como a 'intenção estética' e a 'reação estética', ocorreu (p.157).

É importante ressaltar que essa intencionalidade pode não ser conseguida satisfatoriamente, o que seria a expressão de obras que não alcançam seu objeto; e de que o fato de ter uma intencionalidade não liberta o autor de contradições que estarão refletidas na sua obra, sem necessariamente a empobrecer. O ponto de vista terá a ver com a posição do autor diante da realidade e as suas possibilidades de conseguir a particularidade do real refletido. ${ }^{18}$ Nas palavras de Lukács (1997):

$\mathrm{Na}$ sociedade, cada homem existe numa determinada situação de classe. à qual naturalmente pertence a inteira cultura do seu tempo; não pode assim haver nenhum conteúdo de consciência que não seja determinado pelo hic et nunc da situação atual [...] uma consciência pretensamente livre de liames sociais, que trabalha por si mesma, puramente a partir do interior, não existe e ninguém jamais conseguiu demonstrar sua existência (p.67)

Na realidade, está-se afirmando que existe sempre um projeto consciente de autoria que traz implícita uma visão sobre a realidade refletida, que pode ser expresso de formas as mais diversificadas, ultrapassando as classificações sobre o ponto de vista da teoria literária, embora não se possa prescindir delas para a crítica da obra.

O tema e a forma do signo ideológico estão indissoluvelmente ligados, e nāo podem, por certo, diferenciar-se a não ser abstratamente. Tanto é verdade

1s Possibilidade que tem a ver, também, com o dominio da técnica socialmente alcançada pelo período histórico da realização da obra e com a genialidade da autoria. 
que, em última análise, são as mesmas forças e as mesmas condições que dão vida a ambos (Bakhtin, 1990:45).

Captar a tomada de posição do artista frente à particularidade refletida na obra apresenta dificuldades, só sendo possível quando se penetra em todos os momentos de elaboração do objeto, pois, quanto mais imanente, mais trabalhoso é o percebê-la.

Se o conteúdo do psiquismo é tão social quanto a ideologia, por outro lado, as manifestações ideológicas são tão individuais (no sentido ideológico deste termo), como psiquicas. Todo produto da ideologia leva consigo o selo da individualidade do seu ou dos seus criadores, mas esse próprio selo é tão social quanto todas as outras particularidades e signos distintos das manifestaçōes ideológicas. Assim, todo signo, inclusive 0 da individualidade, é social (Bakhtin, 1990:59).

A relação entre conteúdo e forma está sempre indissociada; a intenção do autor (do sujeito) é objetivada de uma determinada forma numa obra de arte, o que confere a essa atividade humana um movimento dialético específico. O momento pessoal tem importância constitutiva de toda objetividade e, contraditoriamente, é imprescindivel à ultrapassagem de uma individualidade especifica através de um deslocamento do cotidiano imediato:

O mundo da obra de arte, no qual se produz essa objetivação que assim pöe à prova a subjetividade, é um reflexo da realidade objetiva, uma mimese que considera e reproduz do ponto de vista desse processo criador o mundo dado ao homem, tanto o produzido e elaborado por ele, como o que existe, com independência em relação à humanidade (Lukács, v.2, 1966-7:265).

Em Vidas secas não há a busca de equilíbrio, de neutralização das contradições, mas, ao contrário, a explicitação máxima das determinações da convivência de contradições, o que permite a representação de uma dada realidade e, ao mesmo tempo, o surgimento de possibilidades de sua superação ao representar uma aproximação com a essencialidade e a totalidade das relações que compõem essa realidade. Nessa conexão, chega-se ao típico, pois a verdade da forma é a máxima intensificação da verdade real do contúido refletido (Lukács, 1978:282). 
Ao se analisar uma obra de arte, percebe-se (quando isso é possível), ao mesmo tempo, a personalidade do criador e a superação desta. Nessa confluência tem-se o ponto de vista, a autoria. É o princípio da seleção do real e da montagem da obra que pode elevá-la ou rebaixá-la, tornando-a uma verdadeira arte, ou reduzindo-a a uma expressão artística fadada à morte precoce:

Nesse sujeito criador se decide a que nivel se realiza a unificação da qualidade puramente subjetiva com a verdade histórico-social e se nessa unidade não deve ficar mais que um mero reflexo da particularidade ou há de despertar em si as mais amplas formas vitais da subjetividade (desde a familia até a humanidade) (Lukács, v. $2,1966-7: 282$ ).

A crítica de arte, então, precisa encontrar o caminho escolhido pelo autor para expressar uma determinada realidade histórica; captando, através do uso de categorias intelectivas, a relação dialética explicitada pelo autor na obra, que necessariamente apresentará um ponto de vista de um sujeito particular e, ao mesmo tempo, expressará uma possibilidade da humanidade em relação à resolução das questões selecionadas pelo autor. Como afirma Antonio Candido (1993):

O meu propósito é fazer uma critica integradora, capaz de mostrar (não apenas enunciar teoricamente, como é hábito) de que maneira a narrativa se constitui a partir de materiais não literários, manipulados a fim de se tornarem aspectos de uma organização estética regida pelas suas próprias leis, não as da natureza, da sociedade ou do ser (p.9).

A vida em sua plenitude está contida na obra de arte, como afirma Bakhtin (1993), a forma estética tem o poder de transferir essa plenitude para um outro plano, que, no entanto, nunca pode significar, do ponto de vista da crítica, isolamento de partes dessa expressão artística, mas, ao contrário, necessita captar esse momento único em sua plenitude, seguindo o projeto do artista:

Não pode ser destacado da obra de arte um elemento real qualquer como sendo conteúdo puro, como, aliás, realiter não há uma forma pura: o conteúdo e a forma se interpenetram, são inseparáveis, porém, também são indissolúveis para a análise estética, ou seja, são grandezas de ordem diferentes: para que a forma tenha significado puramente estético, o conteúdo que a envolve deve ter um sentido ético e cognitivo possivel, a forma 
precisa do peso extra-estético do conteúdo, sem o qual ela não pode se realizar enquanto forma (Bakhtin,1993:37).

Cada obra de arte representa um mundo que precisa ser entendido e desvendado; busca-se, quando se trata da análise do ponto de vista, a forma concreta pela qual a subjetividade (autor/a) escolheu para dizer e construir aquele mundo artístico: se através de personagens, se através de marcas do narrador, se pela confluência dos dois, ou por qualquer aspecto novo que elaborou. Dentro dessa concepção, cada obra é um mundo que se esgota na sua relação singular com a realidade. Podem-se dizer várias coisas sobre um conjunto de uma obra, mas só a análise de cada obra de per si permitirá a leitura imanente e global daquela criação artística. Essas duas formas de analisar os autores possuem características próprias que precisam ser observadas pela crítica. Os caminhos e resultados são diferentes, não melhores, e, normalmente, se complementam.

A análise imanente de um texto literário necessita ultrapassar a materialidade discursiva para chegar à intencionalidade valorativa da obra (vale ressaltar que não se está defendendo didatismos nem apologias políticas, mas a intencionalidade de um sujeito que vive o mundo, reflete sobre ele e se posiciona de forma crítica). Descobrir o tipo de narrador, a relação entre as personagens, a trama, a forma do discurso etc., significa começar a análise critica, que só poderá ter èxito se, após ou concomitante a essa fase, promover uma ultrapassagem para uma análise totalizante da obra, na medida em que toda expressão artística é realizada por uma subjetividade que carrega uma perspectiva sobre seu tempo e devenir históricos. 


\section{REFER R̂NCIAS BIBLIOGRÁFICAS}

BAKHTIN, Mikhail. Estética da criação verhal. Tradução de Maria Ermantina Galvão Gomes. São Paulo: Martins Fontes, 1992.

BAKHTIN, Mikhail. Marxismo e filosofia da linguagem. Tradução de Michel Lahud e Yara Frateschi Vicira. São Paulo: Hucitec. 1990.

CANDIDO, Antônio. Ficção e Confissão: ensaios sobre Graciliano Ramos. Rio de Janeiro: Ed. 34, 1992.

RAMOS, Graciliano. Vidas secas. 69. ed. Rio de Janeiro/São Paulo: Record, 1995.

RAMOS, Graciliano. Infância. 31. ed. Rio de Janeiro/ São Paulo: Record, 1995.

RAMOS. Graciliano. Memórias do cárcere. 29. ed. 2 v. Rio de Janerro/São Paulo: Record, 1994.

RAMOS, Graciliano. São Bernardo. 40. ed. Rio de Janeiro: Record. 1983.

JAMESON, Fredric. Pós-Modernismo - A lógica cultural do capitalismo tardio. Tradução de Maria Elisa Cevasco. São Paulo: Ática, 1996.

JAMESON, Fredric. O inconsciente politico - A narrativa como ato socialmente político. Tradução de Valter Lellis Siqueira. São Paulo, Ática: 1981.

JAMESON, Fredric. Os marxistas e a Arte. Tradução de Iumna Maria Simon (Coord.). Rio de Janeiro: Civilização Brasileira, 1967.

LUKÁCS, Georg. Teoria do romance. Tradução de Alfredo Margarido. Lisboa: Editorial Presença, [s.d.].

IUKÁCS, Georg. O Trahalho. Tradução de Ivo Tonet. Maceió: 1997. mimeo.

LUKÁCS, Georg. Ontologia dell'essere sociale - mova biblioteca di cultura. Torino: Editori Riuniti, 1981.

LUKȦCS, Georg. Os principios ontológicos fundamentais de Marx. Tradução de Carlos Nelson Coutinho. São Paulo: Ciências Humanas, 1979. 
LUKÁCS, Georg. Introdução a uma estética marxista. Tradução de Carlos Nelson Coutinho e Leandro Konder. Rio de Janeiro: Civilização Brasileira, 1978.

LUKÁCS, Georg. Marxismo e teoria da literatura. Rio de Janeiro: Civilização Brasileira, 1968. A fisionomia intelectual dos personagens artísticos.

LUKÁCS, Georg. Estética: la peculiaridad de lo estetico. $4 \mathrm{v}$. Barcelona/México: Grijalbo. 1966-67.

LUKÁCS, Georg. Ensaios sobre literatura. Rio de Janeiro: Civilização Brasileira, 1965.

MAGALHÃES, Belmira et al. Da linguagem ao poder. Maceió: EDUFAL, 1997

MARX, Karl. A questão Judaica. 2. ed. São Paulo: Ed. Moraes, 1991

MARX, Karl. Elementos fundamentales para la critica de la economia politica. (GRUNDISSE) 1857-1858. México: Siglo XXI , 1978

MARX, Karl. A ideologia Alemã. Tradução de Waltensir Dutra e Florestan Fernandes. Rio de Janeiro: Zahar, 1965.

RAMOS, Clara. Cadeia. Rio de Janeiro: José Olympio, 1992.

RAMOS, Ricardo. Graciliano: retrato fragmentado. S. Paulo: Siciliano, 1979.

SCHWARZ, Roberto. Ao vencedor as batatas. 4. ed. São Paulo: Duas Cidades, 1992.

SCHWARZ, Roberto. Um mestre na periferia do capitalismo. São Paulo: Livraria Duas Cidades, 1991.

TONET, Ivo. Mercado e liberdade. Maceió: EDUFAL, 1997.

VAISMAN, Ester. A ideologia e sua determinação ontológica. Ensciio, S. Paulo, n. 17-18, p. 399-444, 1989.

WILLIAMS, Raymond. Marxismo e literatura. Tradução de Waltensir Dutra. Rio de Janeiro: Zahar, 1979.

WILLIAMS, Raymond. O campo e a cidade: S. Paulo: Companhia das I.etras, 1989. 